\title{
Resource recovery from wastewater containing hazardous oxoanions by hydrothermal mineralization
}

\author{
T. Itakura ${ }^{1}$, R. Sasai ${ }^{2} \&$ H. Itoh $^{2}$ \\ ${ }^{I}$ Department of Applied Chemistry, Graduate School of Engineering, \\ Nagoya University, Japan \\ ${ }^{2}$ EcoTopia Science Institute, Nagoya University, Japan
}

\begin{abstract}
We developed a new treatment method for wastewater containing various harmful ions such as arsenite, arsenate, boric, fluoride and fluoroboric ions by hydrothermal mineralization using $\mathrm{Ca}(\mathrm{OH})_{2}$ as a mineralizer. As a result, complete recovery of these ions was attained regardless of the initial concentration and oxidation number of these harmful ion species in wastewater. Therefore, the present hydrothermal treatment using $\mathrm{Ca}(\mathrm{OH})_{2}$ mineralizer is recommended as one of the most effective techniques to remove these ions from wastewater and recover them as recyclable resource.

Keywords: hydrothermal mineralization, arsenite, arsenate, recovery.
\end{abstract}

\section{Introduction}

Various oxoanions such as arsenite and boric acid have high toxicity against human health and the environment. They are important resource, however, for plating or advanced material manufacturing industries, from which the wastewater containing these oxoanions is generated everyday. Several methods to remove them have been already reported by using adsorption, electrocoagulation, membrane and biological techniques [1-5]. But, these methods have the following problems. (1) Removal yield is low. (2) The applicable concentration range is narrow. In addition, used adsorbent or collected residues are still hazardous wastes, so that they must be treated by proper method, though it is very difficult to convert them to recyclable resource in various industries. These problems are caused by the difficulty to recover these oxoanions as stable 
solid precipitates with low solubility in water. The establishment of recycling system of these hazardous compounds will be one of the world-important issues, especially, in Japan, which is poor in natural mineral.

In the present study, the recovery method of boron, fluorine and arsenic from wastewater containing fluoride, boric, fluoroboric, arsenite and arsenate ions were developed to produce reusable minerals by the hydrothermal treatment, which was analogous to the formation process of minerals in nature [6].

\section{Experimental}

Model synthetic wastewaters containing 1-3000 ppm of boric, fluoroboric, arsenite and arsenite ions were prepared by dissolving $\mathrm{B}_{2} \mathrm{O}_{3}$ (Wako Pure Chemical Industries, Ltd.), hydrofluoric acid (48 wt percent, chemical supplier: ditto), fluoroboric acid (48 wt percent, ditto), $\mathrm{As}_{2} \mathrm{O}_{3}$ (ditto), $\mathrm{Na}_{2} \mathrm{HAsO}_{4}$ (ditto) in distilled and deionized water. These model wastewaters $(30 \mathrm{ml})$ were sealed in a pressure vessel lined with fluorocarbon resin together with reagents. Mineralizer $\mathrm{Ca}(\mathrm{OH})_{2}$ was added into the vessel and in some cases, $\mathrm{H}_{3} \mathrm{PO}_{4}$ or $\mathrm{H}_{2} \mathrm{O}_{2}$ was also added in order to increase recovery yield. Hydrothermal treatments were carried out by leaving the vessel in a dry oven for $2-36 \mathrm{~h}$ at $100-200^{\circ} \mathrm{C}$. After the hydrothermal treatment, the vessels were cooled down in atmospheric air for $1 \mathrm{~h}$. Precipitates obtained by the hydrothermal treatment were filtered and collected.

The precipitates were identified by X-ray diffraction (XRD: RIGAKU Rint2500) using $\mathrm{CuK} \alpha$ radiation. The microstructural observation and qualitative element analysis of the precipitates were performed by scanning electron microscopy (SEM: JEOL JSM-T20) equipped with energy dispersive X-ray spectrometer (EDS: JED-2140). Thermometric analysis of the precipitates was carried out by thermogravimetry and deferential thermal analysis (TG-DTA: RIGAKU Thermo Plus2 TG8120). Quantitative element analysis of the solvent obtained after hydrothermal treatment was carried out by the inductively couple plasma-atomic emission spectrometry (ICP-AES: Perkin-Elmer Optima3300DV). Concentration of fluoride ion in the treated-water was measured by ion chromatograph (Shimadzu, Shim-pack IC-A3) with conductivity detector (Shimadzu, CDD-10A). Quantitative analysis of the arsenate in water was carried out by molybdenum blue method. Oxidation to determine the total arsenic content in the solvent was carried out by hydrothermal oxidation in concentrated $\mathrm{HNO}_{3}$ aqueous solution $\left(0.2 \mathrm{dm}^{3} / 10\right.$ $\mathrm{dm}^{3}$ of treated-water) at $200^{\circ} \mathrm{C}$ for $12 \mathrm{~h}$.

\section{Results and discussion}

\subsection{Recovery of $F$ from wastewater containing fluoride ion}

Figure 1 shows the ion chromatograms of the model wastewater before and after the hydrothermal treatment using $0.5 \mathrm{~g}$ of $\mathrm{Ca}(\mathrm{OH})_{2}$ as mineralizer at $200^{\circ} \mathrm{C}$ for 4h. The peak of fluoride ion was observed in the chromatogram of wastewater before the treatment and its concentration was $18 \mathrm{ppm}$. On the other hand, the 
peak disappeared after the treatment. This suggests that the fluoride ion in the wastewater is completely consumed to form precipitates under the hydrothermal conditions using $\mathrm{Ca}(\mathrm{OH})_{2}$ mineralizer. XRD patterns of the precipitates before and after the treatment exhibited that they consisted of $\mathrm{CaF}_{2}$. However, the concentration of fluoride ion in the treated-water was below enough compared with the concentration that is calculated from the solubility of $\mathrm{CaF}_{2}$. It is considered that all fluoride ions in the model wastewater would be precipitated as $\mathrm{CaF}_{2}$ under the hydrothermal condition. Additionally, it is expected that $\mathrm{CaF}_{2}$ produced under hydrothermal condition may prevent the redissolution in the cooling process.

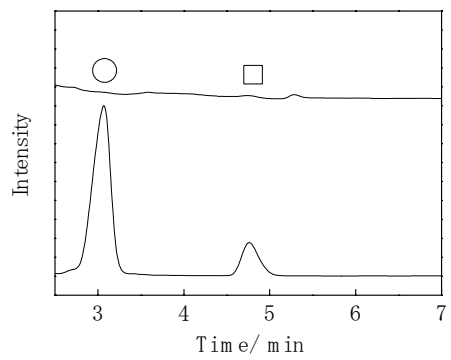

Figure 1: Ion chromatograms of the wastewater before (a) and after (b) the hydrothermal treatment. $\circ$; $\mathrm{F}^{-}, \square ; \mathrm{CO}_{3}{ }^{2-}\left(\mathrm{F}-; 7000 \mathrm{ppm}, \mathrm{Ca}(\mathrm{OH})_{2}\right.$; $\left.0.5 \mathrm{~g}, 200^{\circ} \mathrm{C}, 4 \mathrm{~h}\right)$.

Result of SEM observation of the precipitates obtained before and after the hydrothermal treatment showed that the crystallinity and crystal size of $\mathrm{CaF}_{2}$ increased dramatically by the hydrothermal treatment. Thus, the recovery of fluorine from wastewater was achieved by decreasing dissolution rate of $\mathrm{CaF}_{2}$ at room temperature because of decrease in specific surface area. Therefore, the present hydrothermal mineralizing treatment can recover fluorine completely from wastewater using the minimum amount of $\mathrm{Ca}(\mathrm{OH})_{2}$ required to form $\mathrm{CaF}_{2}$.

\subsection{Recovery of B from wastewater containing boric acid}

Figure 2 shows the result of hydrothermal mineralization treatment for the model wastewater containing $500 \mathrm{ppm}$ of boron in case of adding $\mathrm{Ca}(\mathrm{OH})_{2}$ and $\mathrm{H}_{3} \mathrm{PO}_{4}$. It is found that boric acid in the model wastewater decreases considerably in these treatments. However, the concentration was still higher than $100 \mathrm{ppm}$ in case of using only $\mathrm{Ca}(\mathrm{OH})_{2}$. The reason may be caused by redissolution of the precipitate during the cooling process after hydrothermal treatment. On the other hand, the concentration of boron in the treated-water decreased to ca. $5 \mathrm{ppm}$ in case of using both $\mathrm{Ca}(\mathrm{OH})_{2}$ and $\mathrm{H}_{3} \mathrm{PO}_{4}$. XRD pattern showed that the mineral formed in this process is $\mathrm{Ca}_{2} \mathrm{~B}_{2} \mathrm{O}_{5} \cdot \mathrm{H}_{2} \mathrm{O}$ (parasibirskite) and $\mathrm{Ca}_{5}\left(\mathrm{PO}_{4}\right)_{3}(\mathrm{OH})$ (hydroxyl apatite). In order to clarify the crystallization mechanism of calcium phosphate, the variation of diffraction patterns during hydrothermal treatment 
was examined in detail. Diffraction peaks of $\mathrm{CaHPO}_{4} \cdot \mathrm{H}_{2} \mathrm{O}$ observed before the treatment disappeared gradually with an increase in treatment time. New diffraction peaks of both $\mathrm{CaHPO}_{4}$ and $\mathrm{Ca}_{10}\left(\mathrm{PO}_{4}\right)_{6} \cdot 5 \mathrm{H}_{2} \mathrm{O}$ appeared after the hydrothermal treatment for $6 \mathrm{~h}$. Then, the diffraction peaks originated from only $\mathrm{Ca}_{10}\left(\mathrm{PO}_{4}\right)_{6} \cdot 5 \mathrm{H}_{2} \mathrm{O}$ was observed, when treatment time became longer than $12 \mathrm{~h}$. These results indicates that the $\mathrm{CaHPO}_{4} \cdot \mathrm{H}_{2} \mathrm{O}$ contained in the precipitate before the treatment converts into $\mathrm{Ca}_{10}\left(\mathrm{PO}_{4}\right)_{6} \cdot 5 \mathrm{H}_{2} \mathrm{O}$ via $\mathrm{CaHPO}_{4}$ during longer hydrothermal treatment time. In contrast, the required treatment time to crystallize the $\mathrm{Ca}_{2} \mathrm{~B}_{2} \mathrm{O}_{5} \cdot \mathrm{H}_{2} \mathrm{O}$ from the model wastewater in case of using only $\mathrm{Ca}(\mathrm{OH})_{2}$ was $6 \mathrm{~h}$, which was shorter than that for formation of $\mathrm{Ca}_{10}\left(\mathrm{PO}_{4}\right)_{6} \cdot 5 \mathrm{H}_{2} \mathrm{O}$. Figure 3 shows the SEM photograph obtained by hydrothermal mineralization treatment in using both $\mathrm{Ca}(\mathrm{OH})_{2}$ and $\mathrm{H}_{3} \mathrm{PO}_{4}$. The fine particles of hydroxyl apatite, which would be separated out and grown on the precipitate of $\mathrm{Ca}_{2} \mathrm{~B}_{2} \mathrm{O}_{5} \cdot \mathrm{H}_{2} \mathrm{O}$ and residual $\mathrm{Ca}(\mathrm{OH})_{2}$, can be seen. Therefore, the capsulation with dense intercepting layer of $\mathrm{Ca}_{10}\left(\mathrm{PO}_{4}\right)_{6} \cdot 5 \mathrm{H}_{2} \mathrm{O}$ is considered to prevent the redissolution of $\mathrm{Ca}_{2} \mathrm{~B}_{2} \mathrm{O}_{5} \cdot \mathrm{H}_{2} \mathrm{O}$ into water.

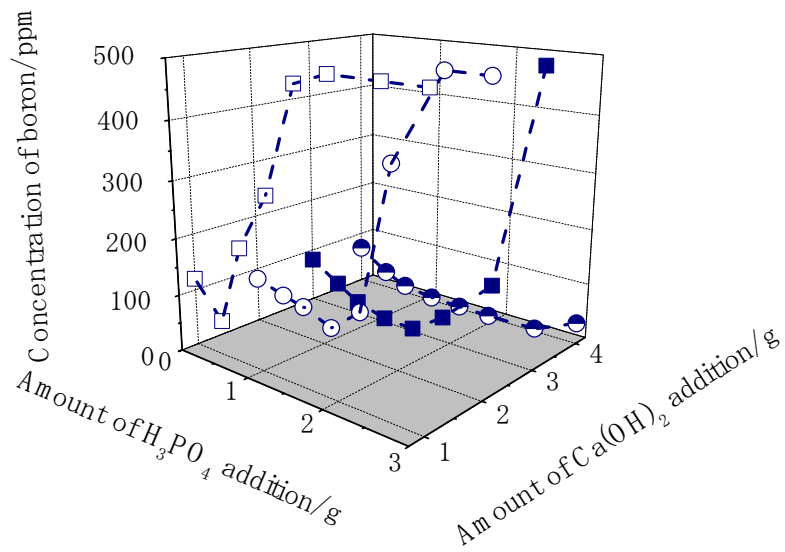

Figure 2: Dependence of the concentration of boron in the treated water after the hydrothermal treatment at $130^{\circ} \mathrm{C}$ for 14 hours on the added amounts of $\mathrm{H}_{3} \mathrm{PO}_{4}$ and $\mathrm{Ca}(\mathrm{OH})_{2}(\mathrm{~B}: 500 \mathrm{ppm})$.

\subsection{Recovery of $B$ and $F$ from wastewater containing fluoroboric acid}

Figure 4 shows the treatment time dependence of the $\mathrm{B}$ and $\mathrm{F}$ concentrations in the wastewater treated at $150^{\circ} \mathrm{C}$. The significant enhancement of recovery yield of fluorine was observed at $2 \mathrm{~h}$ and it was completed by $4 \mathrm{~h}$. However, the recovery yield of boron was only $30 \%$ at $2 \mathrm{~h}$, and then gradually increased. XRD patterns of precipitates before the hydrothermal treatment showed only the diffraction peaks of $\mathrm{Ca}(\mathrm{OH})_{2}$. On the other hand, the diffraction peaks of $\mathrm{CaF}_{2}$ and $\mathrm{Ca}_{2} \mathrm{~B}_{2} \mathrm{O}_{5} \cdot \mathrm{H}_{2} \mathrm{O}$ were observed after the treatment and the intensities of diffraction peaks of $\mathrm{Ca}_{2} \mathrm{~B}_{2} \mathrm{O}_{5} \cdot \mathrm{H}_{2} \mathrm{O}$ increased up to $24 \mathrm{~h}$. Thus, it is expected that the decomposition of fluoroboric acid takes place during the treatment, and the 
recovery of $F$ and $B$ is achieved by forming $\mathrm{CaF}_{2}$ and $\mathrm{Ca}_{2} \mathrm{~B}_{2} \mathrm{O}_{5} \cdot \mathrm{H}_{2} \mathrm{O}$, respectively, in the same manner as the case of wastewater containing fluoride or boric ion only. Therefore, the thermal decomposition of $\mathrm{BF}_{4}{ }^{-}$would occur at the initial stage of treatment (within $4 \mathrm{~h}$ ), and then the mineralization reaction between $\mathrm{Ca}^{2+}$, and $\mathrm{F}^{-} / \mathrm{B}(\mathrm{OH})_{4}{ }^{-}$would be followed.

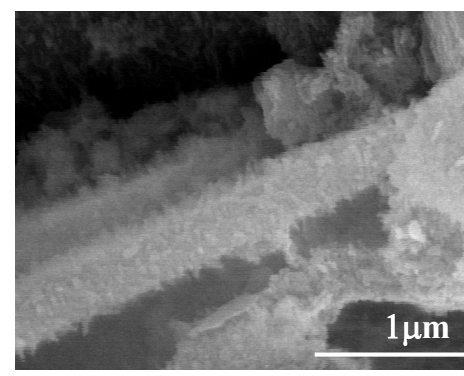

Figure 3: $\quad$ SEM photograph of precipitate obtained by the hydrothermal treatment at $130^{\circ} \mathrm{C}$ for 14 hours $\left(\mathrm{Ca}(\mathrm{OH})_{2}: 3.0 \mathrm{~g}, \mathrm{H}_{3} \mathrm{PO}_{4}: 1.5 \mathrm{~g}, \mathrm{~B}\right.$ : 500ppm).

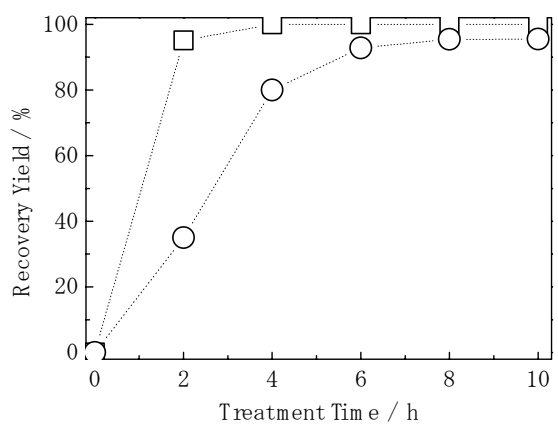

Figure 4: Dependence of recovery yield of $\mathrm{B}$ and $\mathrm{F}$ in the treated-water on treatment time at $150^{\circ} \mathrm{C}\left(\mathrm{BF}_{4}^{-}: 8000 \mathrm{ppm}, \mathrm{Ca}(\mathrm{OH})_{2}: 1.0 \mathrm{~g}\right) . \circ: \mathrm{B}, \square$ : F.

The optimal conditions to recover both $\mathrm{F}$ and $\mathrm{B}$ from model wastewater containing $8000 \mathrm{ppm}$ fluoroboric ion were at $200^{\circ} \mathrm{C}$ for $36 \mathrm{~h}$, when the concentrations of $\mathrm{F}$ and $\mathrm{B}$ were $0.3 \mathrm{ppm}$ and $20 \mathrm{ppm}$, respectively. As described in the previous section, we observed that $\mathrm{Ca}_{2} \mathrm{~B}_{2} \mathrm{O}_{5} \cdot \mathrm{H}_{2} \mathrm{O}$ redissolved in aqueous solution during the cooling process in the case of the treatment for boric acid and the boron concentration in the treated-water was ca. $100 \mathrm{ppm}$ on account of its solubility. However, the boron concentration in the case of fluoroboric acid solution was reduced down to ca. $20 \mathrm{ppm}$ even in the absence of the inhibition reagent against redissolution, phosphoric acid. Therefore, it is considered that the coexistence of $\mathrm{CaF}_{2}$ would affect the increase in recovery yield of boron. 
SEM photographs of a bulky precipitate obtained by the hydrothermal treatment were shown in Figure 5. Three layers were observed in the overview photograph (Figure 5-a). From the results of EDS and XRD analyses, the first surface layer (Figure 5-b) was $\mathrm{CaF}_{2}$, the second layer (Figure 5-c) was the mixture of $\mathrm{CaF}_{2}$ and $\mathrm{Ca}_{2} \mathrm{~B}_{2} \mathrm{O}_{5} \cdot \mathrm{H}_{2} \mathrm{O}$, and the third layer (Figure 5-d) was the mixture of $\mathrm{Ca}_{2} \mathrm{~B}_{2} \mathrm{O}_{5} \cdot \mathrm{H}_{2} \mathrm{O}$ and residual $\mathrm{Ca}(\mathrm{OH})_{2}$. As a result of detailed analysis, the formation of $\mathrm{Ca}_{2} \mathrm{~B}_{2} \mathrm{O}_{5} \cdot \mathrm{H}_{2} \mathrm{O}$ layer in this study would have started in an earlier time range of $2-4 \mathrm{~h}$ and completed for $8-10 \mathrm{~h}$ by heterogeneous nucleation on the surface of $\mathrm{Ca}(\mathrm{OH})_{2}$, after which the suspended $\mathrm{CaF}_{2}$ wrapped over $\mathrm{Ca}_{2} \mathrm{~B}_{2} \mathrm{O}_{5} \cdot \mathrm{H}_{2} \mathrm{O}$ because of the slow sedimentation rate of $\mathrm{CaF}_{2}$ fine particles. Possibly this dense sediment layer would play a role to inhibit the redissolution of $\mathrm{Ca}_{2} \mathrm{~B}_{2} \mathrm{O}_{5} \cdot \mathrm{H}_{2} \mathrm{O}$ into aqueous media.
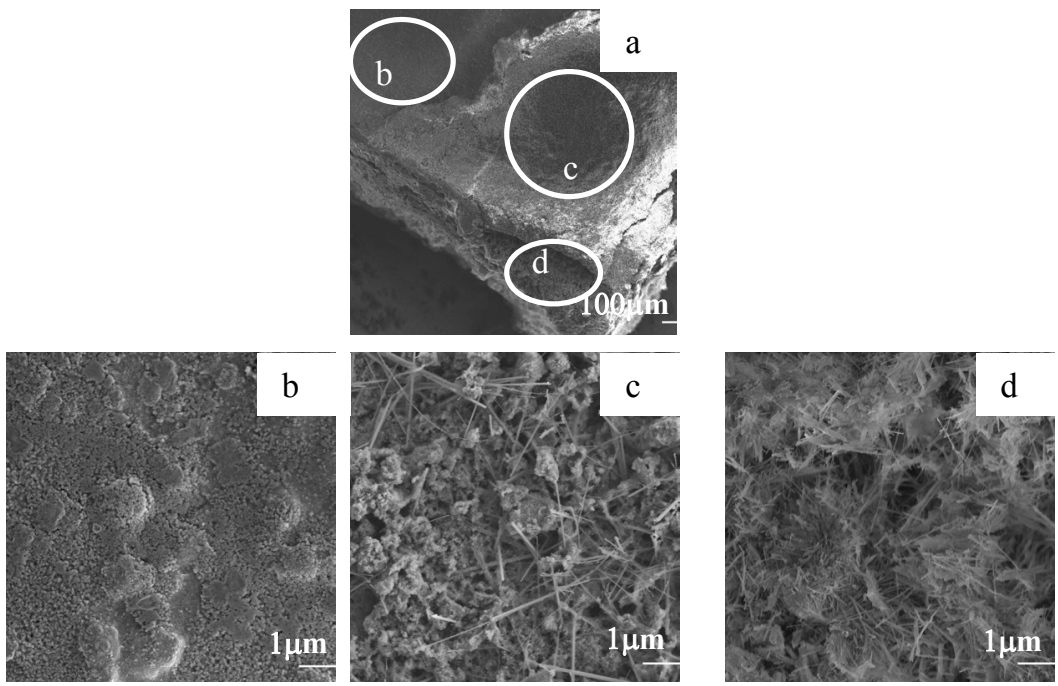

Figure 5: $\quad$ SEM photographs of the precipitates obtained by the hydrothermal treatment. a; over view of precipitate, b; first layer, c; second layer, $\mathrm{d}$; third layer $\left(\mathrm{BF}_{4}^{-}: 8000 \mathrm{ppm}, \mathrm{Ca}(\mathrm{OH})_{2}: 1.0 \mathrm{~g}, 150^{\circ} \mathrm{C}, 24\right.$ hours $)$.

\subsection{Recovery of As from wastewater containing arsenite and arsenate ions}

Treatment time dependence of As concentration in the model wastewater containing $2000 \mathrm{ppm}$ of arsenite $\left(\mathrm{AsO}_{3}{ }^{3-}\right)$ treated at $100-150{ }^{\circ} \mathrm{C}$ with or without $5 \%$ of $\mathrm{H}_{2} \mathrm{O}_{2}$ is shown in Figure 6. Precipitate containing As was observed by adding $\mathrm{Ca}(\mathrm{OH})_{2}$ to the model wastewater, when the concentration of As was reduced to $4 \mathrm{ppm}$. However, this does not meet the standard of discharged water in Japan $(0.1 \mathrm{ppm})$. When the hydrothermal mineralization was performed in using this model wastewater added by $\mathrm{Ca}(\mathrm{OH})_{2}$ only, As concentration showed concave curve against treatment time. The optimum treatment condition showed the minimum As concentration of ca. $0.4 \mathrm{ppm}$, which was one tenth of that 
before the hydrothermal treatment. However, this concentration is still higher than the standard of discharged water. On the other hand, the addition of $\mathrm{H}_{2} \mathrm{O}_{2}$ was found effective to reduce the As concentration down to $0.02 \mathrm{ppm}$ under optimal hydrothermal condition, which is lower than the standard of discharged water. This result verifies that the hydrothermal mineralization is an effective method to recover arsenite $\left(\mathrm{AsO}_{3}{ }^{3-}\right)$ from aqueous media as precipitate, even when the model wastewater contains large amount of arsenite. It is suggested, therefore, that the As recovery mechanism in this treatment is considerably different from that of the conventional lime precipitation method.

Various analyses on the obtained precipitates were carried out in order to clarify the mechanism of the As recovery by the hydrothermal mineralization. From XRD, SEM-EDS and TG-DTA analyses, the precipitate obtained only by addition of $\mathrm{Ca}(\mathrm{OH})_{2}$ was identified as $\mathrm{Ca}_{3}\left(\mathrm{AsO}_{3}\right)_{3}(\mathrm{OH}) \cdot 4 \mathrm{H}_{2} \mathrm{O}$. The same analysis of the precipitate after the hydrothermal treatment using $\mathrm{Ca}(\mathrm{OH})_{2}$ showed that the crystal water was eliminated. The solubilities of $\mathrm{Ca}_{3}\left(\mathrm{AsO}_{3}\right)_{3}(\mathrm{OH}) \cdot 4 \mathrm{H}_{2} \mathrm{O}$ and $\mathrm{Ca}_{3}\left(\mathrm{AsO}_{3}\right)_{3}(\mathrm{OH})$ to water were estimated $13.79 \mathrm{mg} \mathrm{As} / 100 \mathrm{dm}^{3}$ and $29.10 \mathrm{mg}$ As $/ 100 \mathrm{dm}^{3}$, respectively by a simple solubility test. Therefore, the concave tendency in Figure 1 would be caused by the elimination of crystal water from $\mathrm{Ca}_{3}\left(\mathrm{AsO}_{3}\right)_{3}(\mathrm{OH}) \cdot 4 \mathrm{H}_{2} \mathrm{O}$ with an increase in the treatment time. On the other hand, XRD patterns of the precipitates obtained by hydrothermal treatment with $\mathrm{Ca}(\mathrm{OH})_{2}$ and $\mathrm{H}_{2} \mathrm{O}_{2}$ exhibited $\mathrm{Ca}_{5}\left(\mathrm{AsO}_{4}\right)_{3}(\mathrm{OH})$ as final product. Thus, the coexistence of $\mathrm{H}_{2} \mathrm{O}_{2}$ with $\mathrm{Ca}(\mathrm{OH})_{2}$ immediately would give rise to the oxidation of arsenite ion and produce simultaneously arsenate apatite which is known as one of the insoluble natural mineral. Therefore, it is concluded that the hydrothermal mineralization with $\mathrm{Ca}(\mathrm{OH})_{2}$ and $\mathrm{H}_{2} \mathrm{O}_{2}$ is effective to reduce the concentration of $\mathrm{As}$ in the wastewater with arsenite ion $\left(\mathrm{AsO}_{3}{ }^{3-}\right)$, which is usually difficult to remove from wastewater.

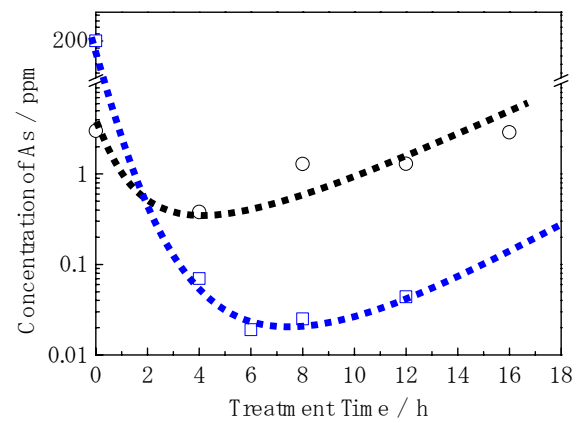

Figure 6: Dependence of the concentration of $A s$ in the treated water on treatment time. $\mathrm{Ca}(\mathrm{OH})_{2} ; 0.36 \mathrm{~g} . \quad \circ ; 150^{\circ} \mathrm{C}$, without $\mathrm{H}_{2} \mathrm{O}_{2}$, $\square$; $150^{\circ} \mathrm{C}$, with $5 \% \mathrm{H}_{2} \mathrm{O}_{2}$. 
Figure 7 shows the initial arsenite $\left(\mathrm{AsO}_{3}{ }^{3-}\right)$ concentration dependence of arsenite in the treated-water using $\mathrm{Ca}(\mathrm{OH})_{2}$ and $3 \%$ of $\mathrm{H}_{2} \mathrm{O}_{2}$ at $100^{\circ} \mathrm{C}$ for $12 \mathrm{~h}$. The residual As concentration was reduced at less than $0.1 \mathrm{ppm}$ except for the case of the wastewater containing $2000 \mathrm{ppm}$ of As. Moreover, it was mostly independent on the initial concentration. This result suggests that the As concentration after the treatment may be determined by only the solubility of the precipitate produced during the hydrothermal mineralization, if the amount of $\mathrm{H}_{2} \mathrm{O}_{2}$ is enough to convert the arsenite ions $\left(\mathrm{AsO}_{3}{ }^{3-}\right)$ into the arsenate ions $\left(\mathrm{AsO}_{4}{ }^{3-}\right)$. Whereas, this hydrothermal conditions for model wastewater containing $2000 \mathrm{ppm}$ of arsenite $\left(\mathrm{AsO}_{3}{ }^{3-}\right)$ could not sufficiently decrease the residual As concentration. However, the addition of $5 \%$ of $\mathrm{H}_{2} \mathrm{O}_{2}$ achieved the As concentration reduction less than $0.1 \mathrm{ppm}$, even when As concentration was $2000 \mathrm{ppm}$. This result shows that the lowest limit of added $\mathrm{H}_{2} \mathrm{O}_{2}$ amount may be fixed by the initial concentration of arsenite dissolved in water. Figure 8 shows the As recovery from model wastewater containing arsenate $\left(\mathrm{AsO}_{4}{ }^{3-}\right)$ or mixture of arsenate $\left(\mathrm{AsO}_{4}{ }^{3-}\right)$ and arsenite $\left(\mathrm{AsO}_{3}{ }^{3-}\right)$ by the treatment with $\mathrm{Ca}(\mathrm{OH})_{2}$ and $3 \%$ of $\mathrm{H}_{2} \mathrm{O}_{2}$. The As in the model wastewater was completely reduced for $12 \mathrm{~h}$ by the treatment. In addition, the treatment for model wastewater containing the mixture of arsenate and arsenite decrease As concentration significantly with 3\% of $\mathrm{H}_{2} \mathrm{O}_{2}$ addition. These results support the speculation for addition of $\mathrm{H}_{2} \mathrm{O}_{2}$ because the maximum concentration of arsenite in this mixed solution was 1000 ppm. The concentration of As in the treated water depends only on the solubility of arsenate apatite when enough amounts of $\mathrm{H}_{2} \mathrm{O}_{2}$ and $\mathrm{Ca}(\mathrm{OH})_{2}$ were added. Therefore, it was elucidated that the hydrothermal mineralization treatment could recover As regardless of the initial concentration and oxidation number of As.

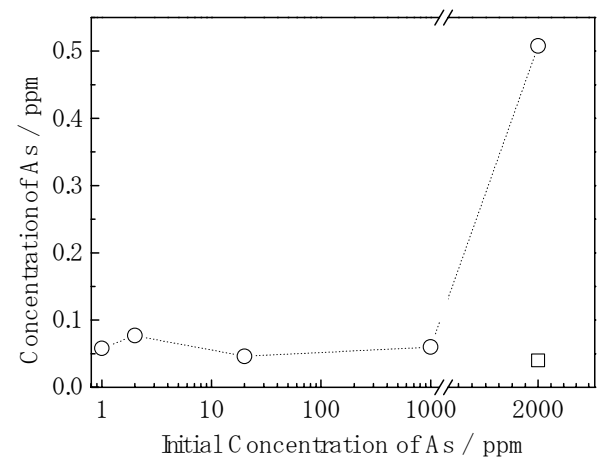

Figure 7: Dependence of the concentration of As in the treated-water on initial concentration of arsenite . $\mathrm{Ca}(\mathrm{OH})_{2} ; 0.36 \mathrm{~g}, 100^{\circ} \mathrm{C}, 0 ; 3 \%$ $\mathrm{H}_{2} \mathrm{O}_{2}, \square ; 5 \% \mathrm{H}_{2} \mathrm{O}_{2}$ 


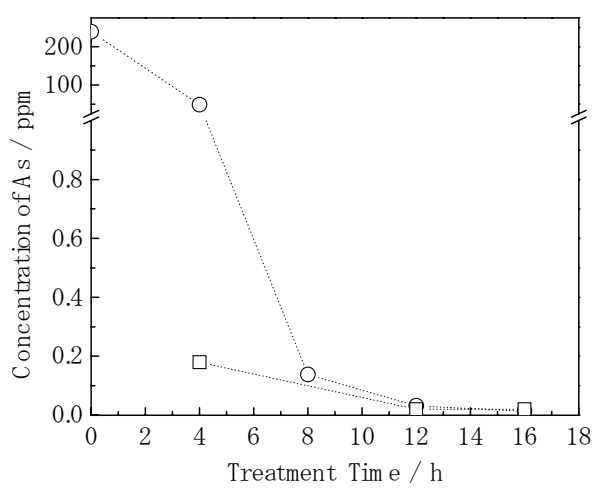

Figure 8: Dependence of the concentration of As in the treated-water on treatment time. $\mathrm{Ca}(\mathrm{OH})_{2} ; 0.36 \mathrm{~g}, 3 \% \mathrm{H}_{2} \mathrm{O}_{2}, 100^{\circ} \mathrm{C}, \mathrm{o} ; \mathrm{AsO}_{3}{ }^{3-}$ $1000 \mathrm{ppm}, \mathrm{AsO}_{4}{ }^{3-} 1000 \mathrm{ppm}, \square ; \mathrm{AsO}_{4}{ }^{3-} 2000 \mathrm{ppm}$,

\section{Conclusions}

The hydrothermal mineralization treatment can recover boron, fluorine and As from model wastewater containing fluoride, fluoroboric, arsenite and arsenate ions. All concentrations of these harmful elements in the synthetic model wastewater were reduced down below the standard of discharged water in Japan. The minerals formed in this treatment had the same composition as natural ones. Thus, they can be reused easily in the production processes of pure raw materials from natural minerals. Furthermore, this treatment is independent on the initial concentration and oxidation number of ions. Therefore, the present hydrothermal mineralization treatment can be used for various kinds of wastewaters.

\section{References}

[1] Kartinen, E. O.; Martin, C. J., An overview of arsenic removal processes. Desalination 1995, 103, (1-2), 79-88.

[2] Al Rmalli, S. W.; Harrington, C. F.; Ayub, M.; Haris, P. I., A biomaterial based approach for arsenic removal from water. Journal of Environmental Monitoring 2005, 7, (4), 279-282.

[3] Ho, L. N.; Ishihara, T.; Ueshima, S.; Nishiguchi, H.; Takita, Y., Removal of fluoride from water through ion exchange by mesoporous $\mathrm{Ti}$ oxohydroxide. Journal of Colloid and Interface Science 2004, 272, (2), 399-403.

[4] Celik, M. S.; Hancer, M.; Miller, J. D., Flotation chemistry of boron minerals. Journal of Colloid and Interface Science 2002, 256, (1), 121131. 
[5] Redondo, J.; Busch, M.; De Witte, J. P., Boron removal from seawater using FILMTEC (TM) high rejection SWRO membranes. Desalination 2003, 156, (1-3), 229-238.

[6] Itakura T., Sasai R., Itoh H., Precipitation recovery of boron from wastewater by hydrothermal mineralization. Water Research 2005, 39 (12), 2543-2548. 